Article

\title{
Developing Multi-Source Indices to Discriminate between Native Tropical Forests, Oil Palm and Rubber Plantations in Indonesia
}

\author{
Inggit Lolita Sari $^{1,2, *}$, Christopher J. Weston ${ }^{1} \mathbb{D}$, Glenn J. Newnham ${ }^{3} \mathbb{D}$ and Liubov Volkova ${ }^{1}$ (D) \\ 1 School of Ecosystem and Forest Sciences, Faculty of Science, The University of Melbourne, \\ Creswick, VIC 3363, Australia; weston@unimelb.edu.au (C.J.W.); lubav@unimelb.edu.au (L.V.) \\ 2 Technology Center and Remote Sensing Data, National Institute of Aeronautics and Space of \\ Indonesia-National Research and Innovation Agency (LAPAN-BRIN), Jakarta 13710, Indonesia \\ 3 CSIRO Land and Water, Private Bag 10, Clayton South, VIC 3169, Australia; Glenn.Newnham@csiro.au \\ * Correspondence: inggit.lolita.sari@brin.go.id
}

Citation: Sari, I.L.; Weston, C.J.; Newnham, G.J.; Volkova, L. Developing Multi-Source Indices to Discriminate between Native Tropical Forests, Oil Palm and Rubber Plantations in Indonesia. Remote Sens. 2022, 14, 3. https:// doi.org/10.3390/rs14010003

Academic Editor: Michael Sprintsin

Received: 14 October 2021

Accepted: 17 December 2021

Published: 21 December 2021

Publisher's Note: MDPI stays neutral with regard to jurisdictional claims in published maps and institutional affiliations.

Copyright: (C) 2021 by the authors. Licensee MDPI, Basel, Switzerland. This article is an open access article distributed under the terms and conditions of the Creative Commons Attribution (CC BY) license (https:// creativecommons.org/licenses/by/ $4.0 /)$.

\begin{abstract}
Over the last 18 years, Indonesia has experienced significant deforestation due to the expansion of oil palm and rubber plantations. Accurate land cover maps are essential for policymakers to track and manage land change to support sustainable forest management and investment decisions. An automatic digital processing (ADP) method is currently used to develop land cover change maps for Indonesia, based on optical imaging (Landsat). Such maps produce only forest and nonforest classes, and often oil palm and rubber plantations are misclassified as native forests. To improve accuracy of these land cover maps, this study developed oil palm and rubber plantation discrimination indices using the integration of Landsat- 8 and synthetic aperture radar Sentinel-1 images. Sentinel-1 VH and VV difference $(>7.5 \mathrm{~dB})$ and $\mathrm{VH}$ backscatter intensity were used to discriminate oil palm plantations. A combination of Landsat-8 NDVI, NDMI with Sentinel-1 VV and $\mathrm{VH}$ were used to discriminate rubber plantations. The improved map produced four land cover classes: native forest, oil palm plantation, rubber plantation, and non-forest. High-resolution SPOT 6/7 imagery and ground truth data were used for validation of the new classified maps. The map had an overall accuracy of 92\%; producer's accuracy for all classes was higher than $90 \%$, except for rubber (65\%), and user's accuracy was over $80 \%$ for all classes. These results demonstrate that indices developed from a combination of optical and radar images can improve our ability to discriminate between native forest and oil palm and rubber plantations in the tropics. The new mapping method will help to support Indonesia's national forest monitoring system and inform monitoring of plantation expansion.
\end{abstract}

Keywords: land cover mapping; oil palm and rubber plantations; Landsat-8; Sentinel-1; decision tree; Indonesia

\section{Introduction}

The increasing global demand for agricultural products has driven the rapid expansion of oil palm and rubber plantations. Globally, between 2000 and 2018, oil palm plantations increased by $>220 \%$ from 7 to $22.5 \mathrm{Mha}$, while rubber plantations increased by $45 \%$ from 5.5 to 8 Mha [1]. As a consequence, considerable areas of native forest have been converted to agricultural land use. In Indonesia, between 2001 and 2016, 43\% (3.96 Mha) of the total 9.2 Mha of native forest loss was due to plantation expansion [2]. This native forest clearing has adversely impacted ecosystems, biodiversity, and the terrestrial carbon cycle [3,4].

Remote sensing is widely used to derive information on land cover and land cover change for natural resources management and environmental applications [5]. Among the remote sensing data used, optical images such as those recorded by the Landsat satellites have been particularly important in supporting long-term forest monitoring of land cover change ( $>40$ years) [6-8]. Currently, Indonesia's National Forest Monitoring 
System (NFMS) uses a visual interpretation (VI) method with 23 land cover classes for land cover mapping [9]. The NFMS is supplemented with an automated digital processing (ADP) method with two land cover classes of forest and non-forest, developed by the Indonesian Land Cover Change Analysis (LCCA) program to produce an annual land cover change map $[10,11]$. Both the VI and ADP maps rely on moderate resolution optical Landsat images, which limit their ability to differentiate between native forest and plantations due to their similar spectral signatures [12-14]. Moreover, tracking the loss of native forests in the tropics using only optical images poses a challenge because of frequent and persistent cloud cover [15].

Although time-series analysis using the VI maps is Indonesia's official method in supporting forest management [16], the underlying visual interpretation is subjective in delineating the land cover classes and is considered an overly time and labor-intensive method for producing maps $[9,17]$. Switching to an ADP method has the significant drawback of the inability to differentiate native forest from plantation classes. However, the ADP method offers the ability to more rapidly and consistently map land cover changes that are measurable, repeatable, and verifiable [18]. Therefore, the development of ADP maps is part of a future strategy to provide accurate land cover change information to track the loss of native forests and to assist policymakers in finding options to deal with the conflicts between demands for agricultural products and ecosystem services such as biodiversity protection.

Satellite-based synthetic aperture radar (SAR) signals can penetrate clouds and provide regular cloud-free images in tropical regions. SAR images can be used to assist in discriminating native forest from plantations due to the sensitivity of backscatter intensity to canopy and tree structure and moisture characteristics $[19,20]$.

SAR images such as ALOS PALSAR L-band have been used to map different forest types across the world. This includes the use of different polarizations (e.g., linear polarized horizontal transmit-horizontal receive $(\mathrm{HH})$ and cross-polarized horizontal transmitvertical receive $(\mathrm{HV})$ ), where backscatter intensity thresholds can be used to discriminate vegetations with distinct structural differences, including tree plantations [21]. Furthermore, studies on the integration of optical and SAR images have improved discrimination of grass/shrubs and forest classes [22].

ALOS PALSAR L-band and Sentinel-1 C-band have significant potential to discriminate differences in the structural form of forests and tree plantations [23,24]. Dong et al. [25] have shown that rubber plantations can be successfully discriminated from native forests in Hainan, China, using an integration of ALOS PALSAR and MODIS images, where rubber plantation phenology was discriminated using MODIS NDVI. However, rubber plantations in the equatorial regions comprise evergreen trees and do not show a clear seasonal variation in solar spectral reflectance signatures.

Remote sensing techniques using integration of optical and SAR images based on decision trees have proven to improve classification accuracy [26]. Integration of multisensor remote sensing data provides complementary information on surface reflectance characteristics (optical) and structural properties (radar). Furthermore, radar images increase temporal data in cloudy tropical regions, which can improve classification accuracy.

This study aims to combine Landsat- 8 and Sentinel- 1 images to discriminate non-forest, native forest, oil palm and rubber plantation land cover classes to support national and international forest monitoring programs. Kalimantan, on the island of Borneo, Indonesia, was selected as a case study due to extensive forest conversion to tree plantations such as oil palm, rubber, and timber plantations [2,27]. During 2000-2017, the area of native forest loss in Borneo was 6.04 Mha, while plantation expansion contributed to $51 \%$ of converted land [28]. Recently, among the five provinces in Kalimantan, the expansion of oil palm and rubber plantations largely occurred in West Kalimantan, followed by Central Kalimantan and East Kalimantan [29,30]. The rapid and extensive increase of oil palm and rubber is due to the high biophysical suitability of areas within Kalimantan for plantation development. 
Kalimantan also has poor plantation extent mapping, including misclassification of oil palm and rubber plantations as native forest [13,31].

This study aimed to apply multi-source indices and a decision tree to improve the accuracy of Indonesia's ADP mapping of native forests, specifically by identifying oil palm plantation and rubber plantation areas. It is anticipated the improved forest and plantation cover classes and accuracy of the annual maps will enable better monitoring of native forest conversion to plantations and trends in plantation expansion. Moreover, the improved method will support Indonesia's national forest monitoring system to comply with the Intergovernmental Panel on Climate Change (IPCC) requirement for transparent, repeatable, accurate, consistent, and complete land cover change mapping for sustainable forest management, including for sustainable plantation development [32].

\section{Materials and Methods}

\subsection{Study Area}

The study area is situated across four regencies in Kalimantan, namely Barito Timur, Tabalong, Balangan and Paser $\left(0^{\circ} 50^{\prime} 20.32^{\prime \prime}\right.$ S $-2^{\circ} 31^{\prime} 56.61^{\prime \prime} \mathrm{S}$ and $\left.114^{\circ} 54^{\prime} 49.33^{\prime \prime} \mathrm{E}-116^{\circ} 37^{\prime} 22.46^{\prime \prime} \mathrm{E}\right)$ covering an area of over 1.9 million ha [33-35]. The terrain in these regions is variable, from swampy plains to hilly lowlands ranging from sea level up to $1550 \mathrm{~m}$. The land cover consists of $41 \%$ native forests, $14 \%$ oil palm plantations, and $6 \%$ rubber plantations, with the remaining $39 \%$ accounted for by non-forested areas such as settlements, paddy fields, mixed agriculture, shrubs, grasslands, and mining [33-35].

The native forest is dominated by species of the Dipterocarpaceae family, mainly the genus of Shorea, such as Shorea johorensis and Shorea leprosula, and Dipterocarpus, such as Dipterocarpus gracilis, at an elevation below $700 \mathrm{~m}$, and the high-quality timber species Agathis endertii is mostly found at an altitude of 1450-1600 m [36-38]. These endemic trees usually have large trunks (up to $122 \mathrm{~cm}$ in diameter) [36]. Due to past logging history, these forests are classified as secondary forests [9].

The oil palm and rubber plantations in the tropics are evergreen trees $[39,40]$. Oil palm trees (Elaeis guineensis) have single branchless trunks of 12-17 $\mathrm{m}$ height with eight fronds forming a rank in succession. Each frond is $8 \mathrm{~m}$ long and consists of 250-300 leaves that are $1.3 \mathrm{~m}$ long with $6 \mathrm{~cm}$ broad length. Oil palm grows best at a temperature range of $24-28^{\circ} \mathrm{C}$ and mean annual rainfall of $2000 \mathrm{~mm}$ per year or greater [39]. Topographically, oil palm is mainly planted below $200 \mathrm{~m}$ elevation and on flatter areas with slope $<20 \%$.

Rubber trees (Hevea brasiliensis) have cylindrical trunks that branch out at the top, forming a dense canopy. The leaves are in spirals and have three leaflets [41]. The leaves are $3-20 \mathrm{~cm}$ long for the main stalk and $3-10 \mathrm{~cm}$ for the leaflets. Each leaflet is $5-35 \mathrm{~cm}$ long and $2.5-12.5 \mathrm{~cm}$ broad. Similar to oil palm, rubber plantations are mostly grown in lowlands at an elevation of less than $600 \mathrm{~m}$, where the temperature ranges between 20 and $30{ }^{\circ} \mathrm{C}$, annual rainfall rate is $>1500 \mathrm{~mm}$ per year, and the slope is below $30 \%$ [40].

Shrub and grassland areas that are included within the non-forest class are dominated by a mix of shrub species (up to $1.5 \mathrm{~m}$ tall), such as Hyptis capitate, Ageratum conyzoides L., and Eleocharis dulcis, and are usually dense in both drylands or wetlands [42,43]. Sample photos of the native forest, oil palm and rubber plantations, shrubs and grasslands in the study area are shown in Figure 1.

\subsection{Satellite Data and Pre-Processing}

The datasets used to develop plantation discrimination indices were derived from Landsat- 8 and Sentinel- 1 images. The Landsat- 8 images were downloaded from the United States Geological Survey (USGS) (https:/ / earthexplorer.usgs.gov/, accessed on 3 July 2019), and Sentinel-1 images were downloaded from the Alaska Satellite Facility (ASF) (https:/ / www.asf.alaska.edu/, accessed on 3 July 2019). The sensor details, preprocessing, and image details are as follows. 


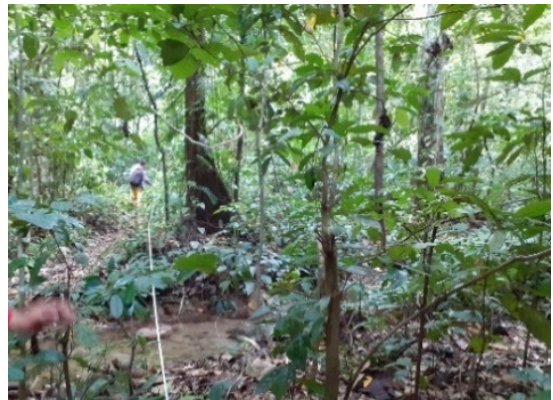

Native forest

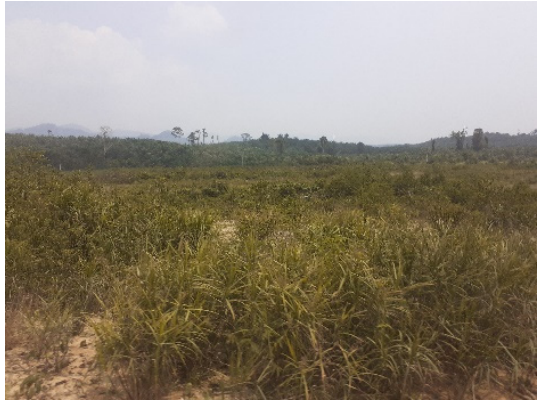

Non-forest of shrub/grass in dryland

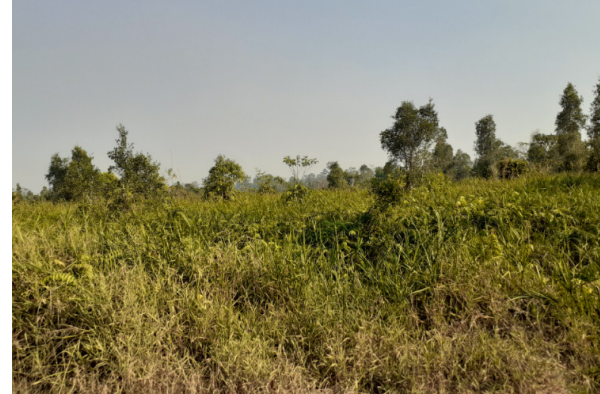

Non-forest of shrub/grass in wetland

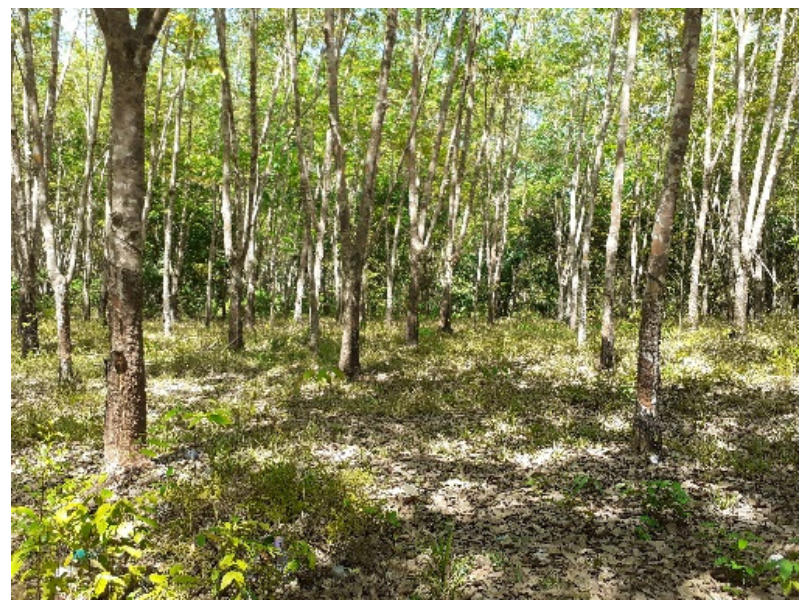

Rubber plantation

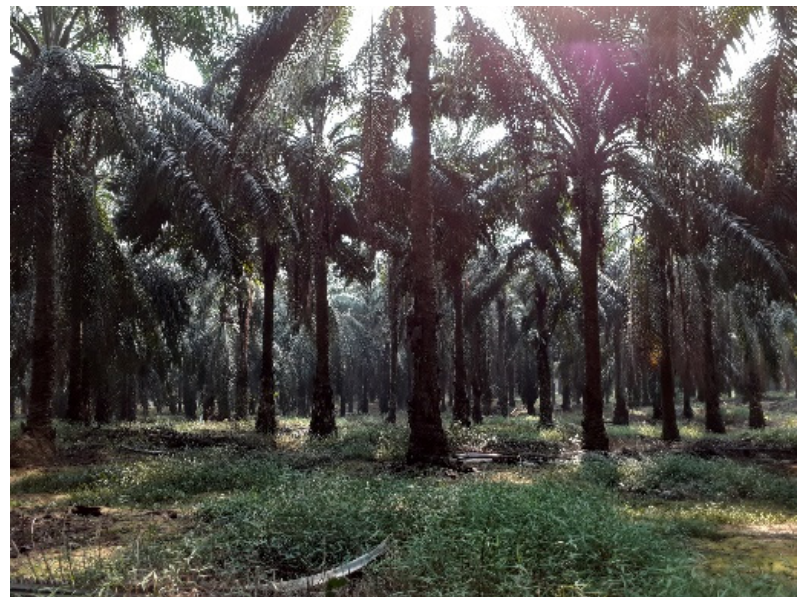

Oil palm plantation

Figure 1. Photos of native forest, oil palm and rubber plantations, non-forest of shrub and grassland in Kalimantan, 2019 (photos by I.L. Sari).

- Landsat-8

The Landsat- 8 satellite has a revisit time of 16 days and consists of two sensors: the Operational Land Imager (OLI) sensor with nine bands ranging from visible to short-wave infrared (SWIR) recorded at $30 \mathrm{~m}$ resolution and the Thermal Infrared Sensor (TIRS) with two thermal bands recorded at $100 \mathrm{~m}$ resolution. For this study, Landsat-8 OLI images were used. The pre-processing steps to produce mosaiced Landsat- 8 images at $25 \mathrm{~m}$ resolution with six multi-spectral image bands (blue, green, red, near infrared, short-wave infrared 1, and short-wave infrared 2) were based on the LCCA method outlined in [10] and consist of scene selection; geometric, radiometric, and terrain correction; cloud masking; and mosaicking of the individual Landsat- 8 images. The current study used 15 Landsat- 8 scenes with date acquisitions provided in Table 1 . Only scenes with less than $50 \%$ cloud cover were selected.

\section{- Sentinel-1}

The Sentinel-1A and Sentinel-1B satellites both include a C-band SAR sensor with frequency $\sim 5.4 \mathrm{GHz}$ (wavelength $\sim 5.6 \mathrm{~cm}$ ) to produce multi-polarized datasets of single $(\mathrm{VV}$ or $\mathrm{HH})$ and dual polarization $(\mathrm{HH}+\mathrm{HV}$ or $\mathrm{VV}+\mathrm{VH})$. The four different polarization modes of Sentinel-1 satellites are VV (vertical transmit-vertical receive), HH (horizontal transmit-horizontal receive), HV (horizontal transmit-vertical receive), and VH (vertical transmit-horizontal receive). The dual-polarization of $\mathrm{VV}+\mathrm{VH}$ bands was used in this study to analyze the backscatter intensity variations for all land cover classes. 
Table 1. Sampling dates and path/row data for the Landsat- 8 and Sentinel-1 images acquired throughout 2018.

\begin{tabular}{|c|c|c|}
\hline \multicolumn{2}{|c|}{ Landsat-8 } & \multirow{2}{*}{ Sentinel-1 (Path 105) } \\
\hline Path 117, Row 61 & Path 117, Row 62 & \\
\hline $\begin{array}{l}\text { 14 April } \\
\text { 30 April } \\
\text { 17 June } \\
4 \text { August } \\
\text { 20 August } \\
\text { 21 September } \\
\text { 26 December }\end{array}$ & $\begin{array}{l}\text { 14 April } \\
\text { 30 April } \\
\text { 1 June } \\
\text { 17 June } \\
\text { 19 July } \\
\text { 20 August } \\
\text { 10 December } \\
\text { 26 December }\end{array}$ & $\begin{array}{l}12 \text { January (row 592) } \\
12 \text { January (row 597) } \\
17 \text { February (row 602) }\end{array}$ \\
\hline
\end{tabular}

Each of the Sentinel-1 satellites can acquire data for the same ground location every 12 days or every six days when combining data from the two satellites. The current study used three scenes of Sentinel-1A Interferometric Wide (IW) swath mode provided in Level-1 Ground Range Detected (GRD) format in descending mode, with a pixel size of $10 \mathrm{~m}$. The acquisition dates for the Sentinel-1 images are shown in Table 1.

The Sentinel-1 IW GRD images were multi-look (averaged) and ground range detected. However, these images required pre-processing to more accurately match ground coordinates and derive the backscatter intensity referred to as sigma nought $\left(\sigma^{\circ}\right)$, with units of decibel $(\mathrm{dB})$. The pre-processing steps were conducted using the SNAP open-source software; the steps consisted of applying an update of precise orbit acquisition information, radiometric calibration, and terrain correction to remove terrain effects using the digital elevation model developed from the SRTM (Shuttle Radar Topography Mission). This was followed by mosaicking the images to produce a $25 \mathrm{~m}$ resampled image.

\subsection{Field Data and Training Sample Collection}

Samples from field data and high-resolution images are required for accurate interpretation of land cover. Ground-truth information for determining the best SAR or optical index and relevant index threshold for discrimination of plantations were obtained from SPOT 6/7 images (resolution $1.5 \mathrm{~m}$ ) and field measurements. The training samples were collected from a group of image regions of interest (ROI); 22 ROIs (12,994 pixels) for native forest, 33 ROIs (11,124 pixels) for rubber, 25 ROIs (13,008 pixels) for oil palm, and 26 ROIs (7648 pixels) for non-forest such as shrub in dryland and wetland regions.

A total of 32 field plots were measured in September 2019, 9 native forest plots, 8 oil palm plantation plots, 6 rubber plantation plots and 9 non-forest plots (shrubs and grass, 7 plots in dryland, and 2 plots in wetland). The plots were selected using a purposive sampling based on a minimum of $16(4 \times 4$ pixels $)$ visibly similar pixels of Landsat- 8 images to represent one hectare of homogeneous land surface. A belt-shaped transect was used to collect information on vegetation characteristics, such as canopy cover, tree density, and ground cover [44], with a sample area of $500 \mathrm{~m}^{2}(5 \times 100 \mathrm{~m})$, which was multiplied by 20 to represent an area of 1 hectare [45].

The canopy cover percentage was measured using a template developed by the USDA [46] and was assessed visually at two sampling locations for each plot. The ground vegetation cover was assessed visually using the step point method to estimate percentage $(\%)$ of live plant and bare soil cover [47]. The diameter at breast height $(1.3 \mathrm{~m})$ of all live trees with a diameter $\geq 5 \mathrm{~cm}$ was measured using a diameter tape. The tree height was measured on 3 to 4 representative trees using a Vertex III [48].

\subsection{Methodological Framework}

Decision trees have been widely used in land cover classification in remote sensing applications [49] and they are often used for integration of multi-source data such as optical and SAR images $[23,50,51]$. In this study, a decision tree was developed to discriminate 
between non-forest, native forest, oil palm and rubber plantations to produce a land cover map for 2018.

The decision tree was applied by integrating forest and non-forest maps produced by Indonesia's LCCA program with indices derived from optical (Landsat-8) images and SAR (Sentinel-1) images to assist in identifying oil palm and rubber plantation areas. The decision tree rules were based on existing optical and SAR indices, specifically: (1) the difference of the two Sentinel- 1 bands (VH and VV), (2) the Grey Level Co-occurrence Matrix (GLCM) texture, (3) spectral indices of Landsat- 8 images, and (4) thresholds from a training sample validated with high-spatial resolution images of SPOT 6/7 and field measurements.

The mapping process to produce the land cover map for 2018 is shown in Figure 2. The decision tree classification was based on a series of binary decisions determined from thresholds applied to the SAR and optical indices. The LCCA forest/non-forest map was used as a root node of the decision tree, while oil palm and rubber plantations were discriminated at subsequent nodes. The steps to determine the indices and threshold for oil palm and rubber plantations discrimination are outlined in Sections 2.6 and 2.7. The decision tree used to produce the land cover map and the subsequent validation of this map using high resolution images are discussed in Section 3.4.

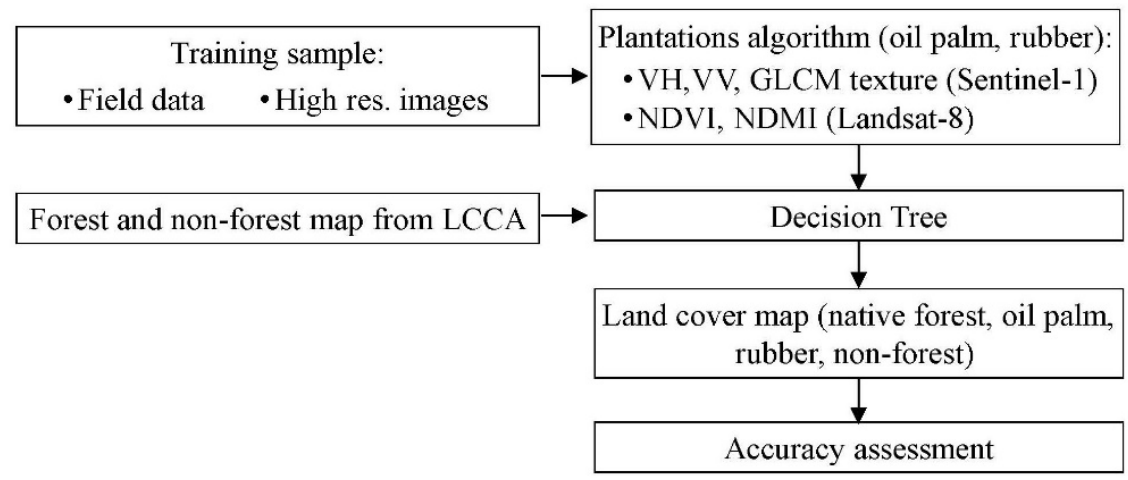

Figure 2. Framework for integration of Landsat-8, Sentinel-1 images, forest/non-forest map, and references data for producing land cover map for 2018.

\subsection{Forest/Non-Forest Map from Landsat}

The LCCA program defines a forest as a group of trees taller than $5 \mathrm{~m}$ with a canopy cover of more than $30 \%$, as specified by Indonesia's Ministry of Forestry $[10,16]$. The LCCA's forest/non-forest map does not explicitly identify plantations, such as oil palm and rubber. These plantations can occur in both the forest and the non-forest classes [10].

The annual LCCA maps with forest/non-forest classes are used to derive a change product of forest loss and forest regrowth for each annual interval [10]. These maps use the succession of Landsat instruments as the primary data, which includes the Thematic Mapper (TM), the Enhanced Thematic Mapper Plus (ETM+), and the OLI sensors.

The production of the LCCA maps involves two main steps, as outlined in [10]. First, image pre-processing consists of manual scene selection, orthorectification, radiometric terrain correction, cloud masking, and mosaicking. Second, multitemporal land cover classification steps consist of developing a forest base from the training sample to determine forest indices and thresholds and application of a multitemporal processing step using a Canonical Probability Network $[7,10]$. The multitemporal process aims to combine and refine the entire time series of individual yearly classification maps and to fill the missing data due to cloud cover. The result of applying these steps is a forest/non-forest map for the entire country each year. The current study used a final forest/non-forest map for 2018 based on the Landsat-8 image data listed in Table 1.

\subsection{Discrimination of Oil Palm Plantation from Native Forest}

Previous studies showed that it is difficult to differentiate between native forest and oil palm plantations using Landsat images in the tropics [12,13]. Thus, the oil palm 
discrimination indices and thresholds were developed from the single-date mosaic of Sentinel-1A SAR images using the training samples derived from ground truth plots and SPOT 6/7 images.

The best performing indices and thresholds were determined by assessing individual Sentinel-1 VH and VV bands, as well as several band combinations including the ratio of $\mathrm{VV}$ and $\mathrm{VH}(\mathrm{VV} / \mathrm{VH})$, the difference of $\mathrm{VH}$ and $\mathrm{VV}(\mathrm{VH}-\mathrm{VV})$, a normalized difference index (NDI) derived from $(\mathrm{VV}-\mathrm{VH}) /(\mathrm{VV}+\mathrm{VH})$, and a gray level co-occurrence matrix (GLCM) texture using reference data and feature separability $[23,24]$.

The GLCM algorithm provides an ability to quantify texture based on mean, variance, homogeneity, and contrast within a pre-defined pixel window [52]. A previous study showed that GLCM variance reduced uncertainty and improved the ability to detect small regions of forest/plantation fragmentation and/or urban development [53,54]. To improve the accuracy of oil palm plantations discrimination, a GLCM variance based on standard deviation [55] with the input band of $\mathrm{VH}-\mathrm{VV}$ and a window of $7 \times 7$ pixels was used.

The identification of relevant oil palm discrimination indices was based on the JeffriesMatusita (JM) value estimated from the deviation between class means and its distance from the training samples. The JM value rates separability between two classes with output ranging from zero to two (two indicates the best feature separability) [56]. JM separability was computed using QGIS [57]. The plantation threshold was determined based on a 95\% confidence interval of feature frequency histogram of oil palm samples, which was then validated visually.

\subsection{Discrimination of Rubber Plantation from Native Forest}

The vegetation indices often utilized for discrimination of rubber plantations are the Normalized Difference Vegetation Index (NDVI), the Normalized Difference Moisture Index (NDMI), and the Enhanced Vegetation Index (EVI) [58-60].

Mapping rubber plantations in the tropics is challenging because a rubber plantation has a similar structure to that of a native forest, and phenological phases may not be captured in optical images due to frequent cloud cover. Previous studies that have attempted to map the extent of rubber plantations using the EVI have shown misclassification with native forest and non-forest classes [61].

Here, we integrated Landsat- 8 and Sentinel- 1 imagery to improve the discrimination between rubber plantations and native forests. Several vegetation indices were evaluated to discriminate between rubber plantations and native forest. The C-band was used to discriminate between rubber and shrubs due to $\mathrm{C}$-band penetration being more sensitive to sparse and low vegetation. The selected indices and thresholds for discrimination of rubber plantations were developed based on similar steps as used for oil palm indices. The vegetation indices that provided the greatest discrimination performance based on the JM values were NDVI and NDMI, as defined below:

$$
\begin{gathered}
\text { NDVI }=\frac{\text { NIR }- \text { RED }}{\text { NIR }+ \text { RED }} \\
\text { NDMI }=\frac{\text { NIR }- \text { SWIR } 1}{\text { NIR }+ \text { SWIR } 1}
\end{gathered}
$$

where RED is the red spectral band $(0.64-0.67 \mu \mathrm{m})$ of the OLI, NIR is the near infrared band $(0.85-0.88 \mu \mathrm{m})$ and SWIR 1 is the first OLI short-wave infrared band $(1.57-1.65 \mu \mathrm{m})$.

\subsection{Accuracy Assessment}

A confusion matrix showing overall accuracy, producer's accuracy, and user's accuracy was used to assess the land cover map based on 784 validation points. The sample size was determined based on stratified random sampling, as outlined in [62], distributed proportionally to native forest, oil palm and rubber plantations, and non-forest classes. The minimum sampling unit was created from a block of $2 \times 2$ pixels in the land cover change map $(50 \times 50 \mathrm{~m})$, which represents a minimum forested area of 0.25 hectares [16]. The land 
cover at each of the validation points was assessed with high-resolution images from SPOT 6/7 recorded in 2018 and accessed using Google Earth.

\section{Results}

\subsection{Field Results}

Field measurement showed great variability of vegetation structure between land cover types. Native forest had the highest tree density and highest canopy cover out of the four classes (Figure 3a,b). Trees in native forests had an average diameter of $19 \mathrm{~cm}$ (Figure $3 \mathrm{~d}$ ), yet some trees had a diameter of up to $80 \mathrm{~cm}$ and almost no bare soil present (Figure 3e).

Oil palm plantations were generally planted in a symmetrical pattern on relatively flat ground with tree density of 160 to 180 trees/ha (Figure 3b), heights of 12 to $17 \mathrm{~m}$ (Figure 3c) and diameters ranging from 50 to $80 \mathrm{~cm}$ (Figure 3d). Rubber plantations had tree densities around 410 trees/ha (Figure 3b), diameters ranging from 10 to $26 \mathrm{~cm}$ (Figure $3 \mathrm{~d}$ ), and heights of 13 to $23 \mathrm{~m}$ (Figure 3c). The average ground cover on rubber plantations was $60 \%$ (Figure 3e).

Shrub and grassland vegetation, on average, were less than $0.84 \mathrm{~m}$ tall, with some shrubs reaching $2 \mathrm{~m}$. Few trees were present in this land class (Figure 1). Field observations suggested that oil palm and rubber plantations may be discriminated based on characteristics of semi-open canopy, gaps between the trees, height, and ground cover vegetation (Figure $3 a-d)$.

\subsection{Algorithm for Mapping Oil Palm Plantation}

The separability of oil palm plantations, native forests and non-forest (shrub/grass) in Sentinel-1 images was analyzed based on the frequency distribution histogram of training samples. Oil palm plantations had a VH backscatter with values between -16 and $-12 \mathrm{~dB}$ (Figure $4 \mathrm{a}$ ), while the VV ranged from -8 to $-4 \mathrm{~dB}$ (Figure $4 \mathrm{~b}$ ). Oil palm plantations also produced the largest $\mathrm{VH}$ and $\mathrm{VV}$ difference $(>7.5 \mathrm{~dB})$ compared to rubber plantations and native forest. However, this index did not clearly discriminate between native forests and rubber plantations (Figure 4e). Oil palm plantations were not easily discriminated using the ratio VV/VH and NDI, as shown in Figure 4c,d.

The GLCM variance was applied to improve the ability to detect oil palm plantations and remove noise in the SAR images. The GLCM variance further increased separability between oil palm plantations and the other classes (Figure $4 \mathrm{f}$ ). This was combined with the oil palm plantation threshold of $\mathrm{VH}$ backscatter to separate oil palm plantations from native forest and non-forest (Figure $4 \mathrm{a}$ ).

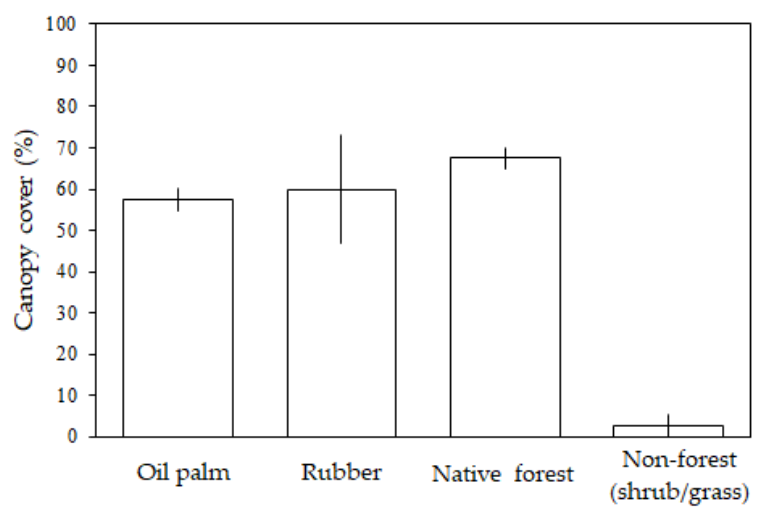

(a)

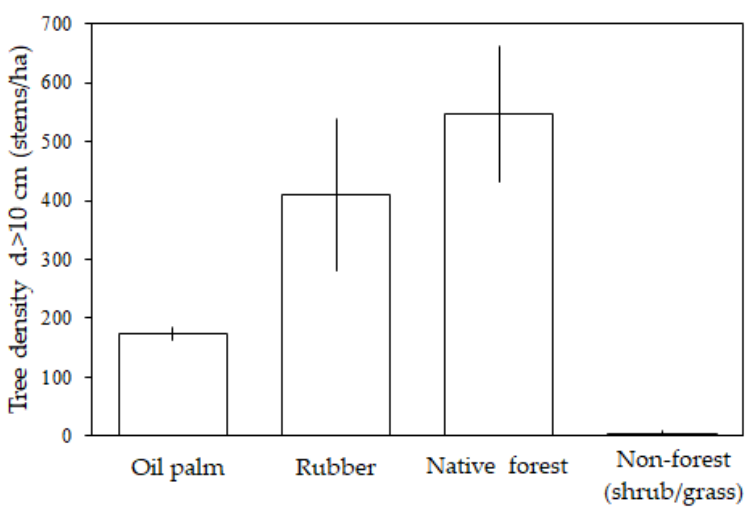

(b)

Figure 3. Cont. 


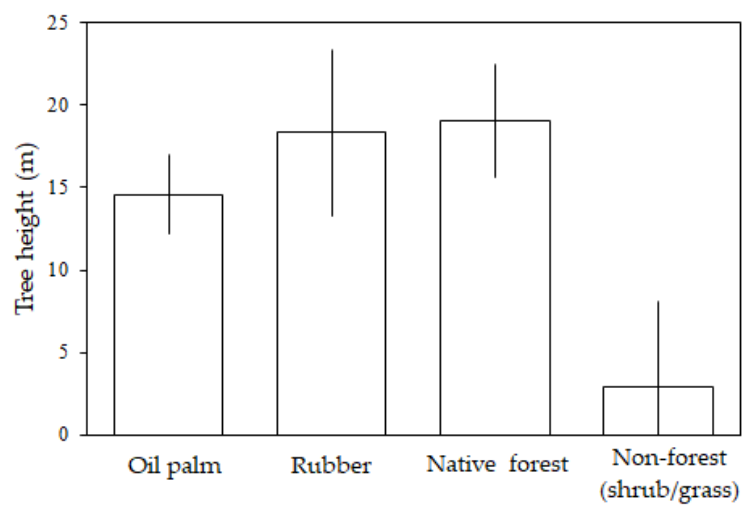

(c)

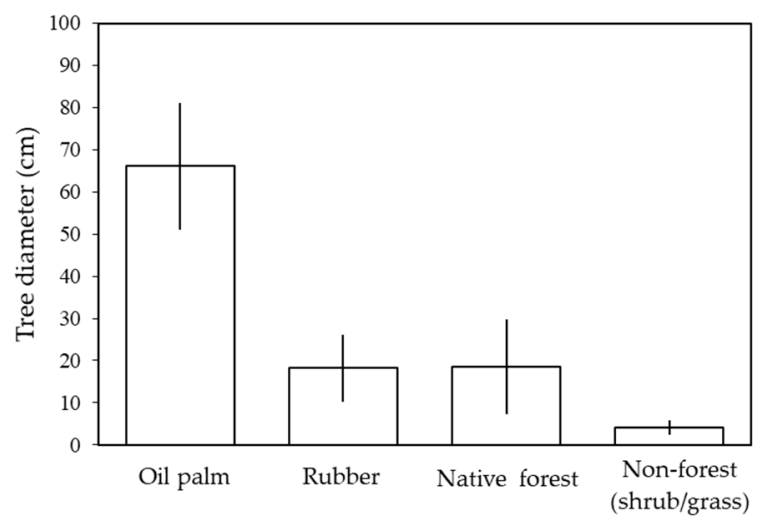

(d)

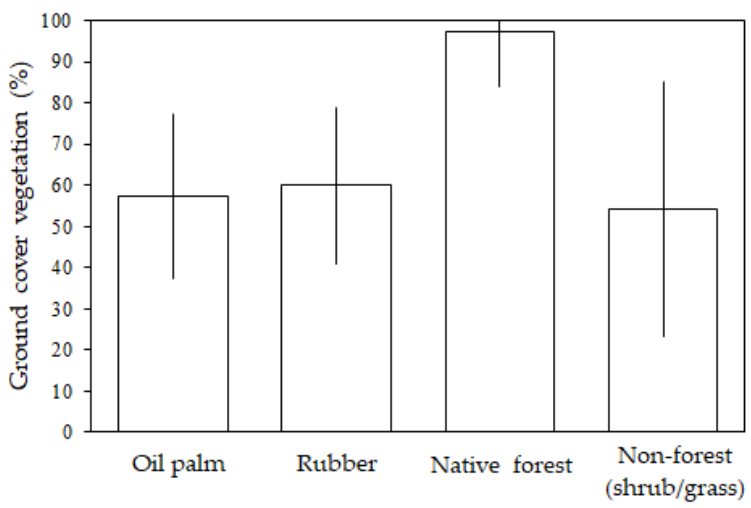

(e)

Figure 3. Structural characteristics for oil palm, rubber, native forest and non-forest (shrub/grass) from field data collection: (a) canopy cover, (b) tree density, (c) tree height, (d) tree diameter, and (e) ground cover vegetation.

Evaluation of class separability was conducted using the JM statistic (Table 2). This showed that, from the training sample, the combination of the GLCM variance and the $\mathrm{VH}$ backscatter resulted in close to complete separability between oil palm plantations and native forest (1.978) and complete separability between oil palm and rubber plantations (2.0). However, these combined indices resulted in low separability between native forest and rubber plantations. Thus, the final indices and thresholds used to detect oil palm plantations were a GLCM variance of less than 40 and a $\mathrm{VH}$ backscatter intensity between -15 and $-13 \mathrm{~dB}$.

Table 2. JM value for oil palm plantation discrimination from native forest and rubber plantation.

\begin{tabular}{cccc}
\hline Image Bands & Native Forest-Oil Palm & Oil Palm-Rubber & Forest-Rubber \\
\hline VV, VH & 1.594 & 1.628 & 1.185 \\
VH - VV, VH & 1.907 & 1.995 & 1.596 \\
GLCM variance, VH & 1.978 & 2.0 & 1.624 \\
\hline
\end{tabular}

\subsection{Algorithm for Mapping Rubber Plantation}

Rubber plantations were discriminated from other classes using NDVI and NDMI. Rubber plantations had relatively high NDVI with values of $0.60-0.80$. However, this NDVI range overlaps with values for native forest $(0.65-0.85)$ and shrubs within the non-forest class (0.60-0.80) (Figure 5a). The discrimination between rubber plantations and native forest was clear when using NDMI (Figure 5b), although there was a significant NDMI overlap between rubber and shrub/grass in the dryland and wetland regions of the study 
area. Thus, the combination of $\mathrm{VV}$ and $\mathrm{VH}$ backscatter of rubber plantations was applied to discriminate the overlap between native forest, rubber plantation and shrub/grassland.

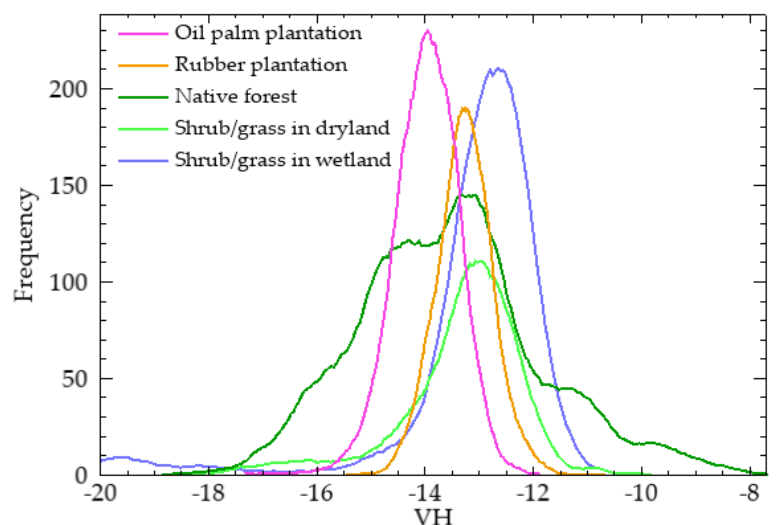

(a)

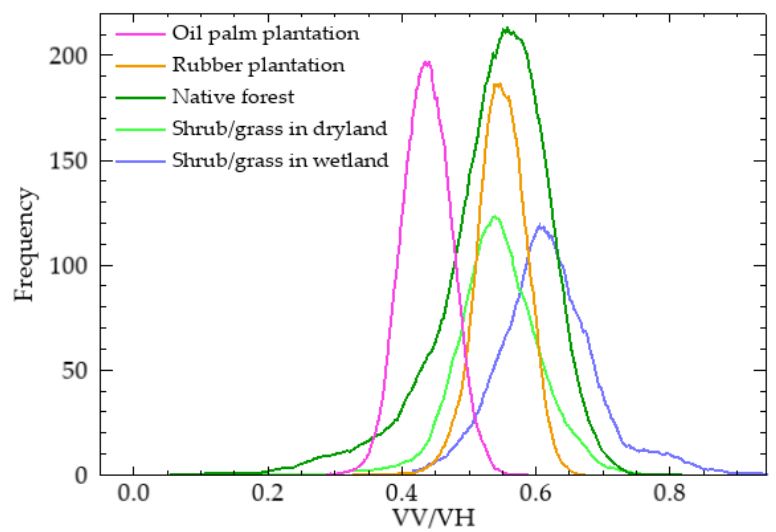

(c)

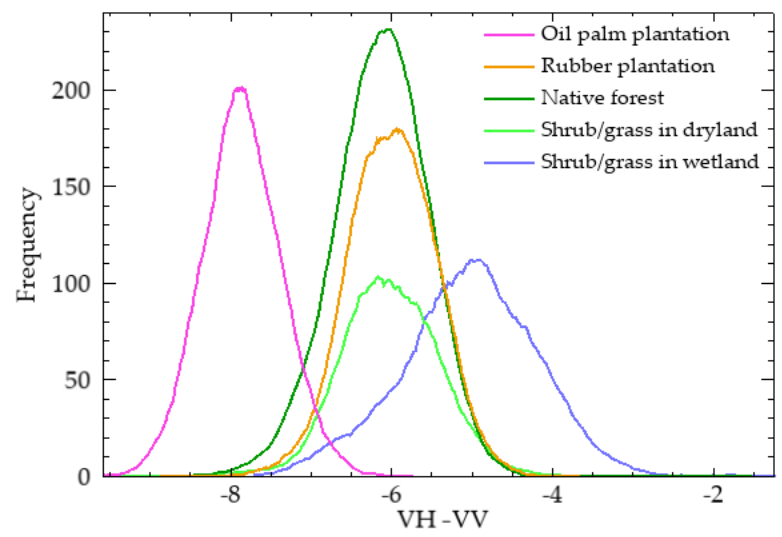

(e)

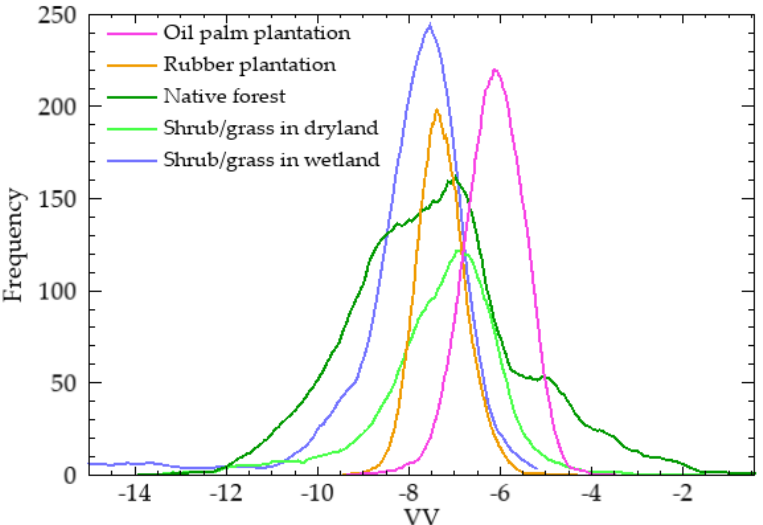

(b)

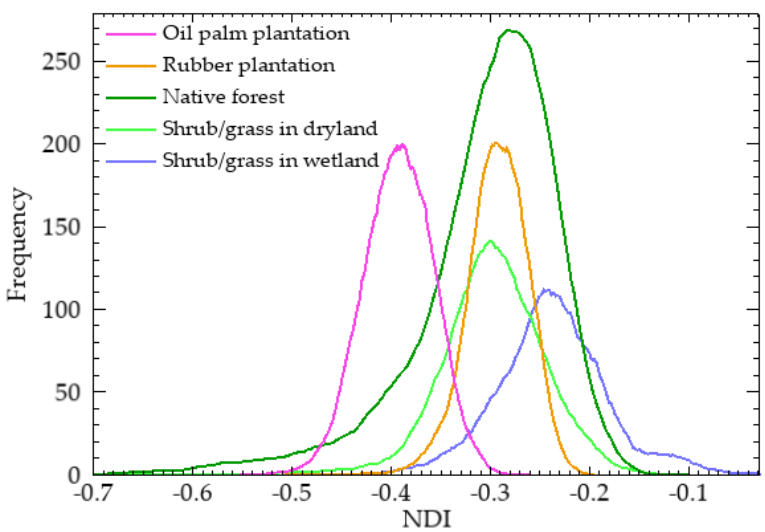

(d)

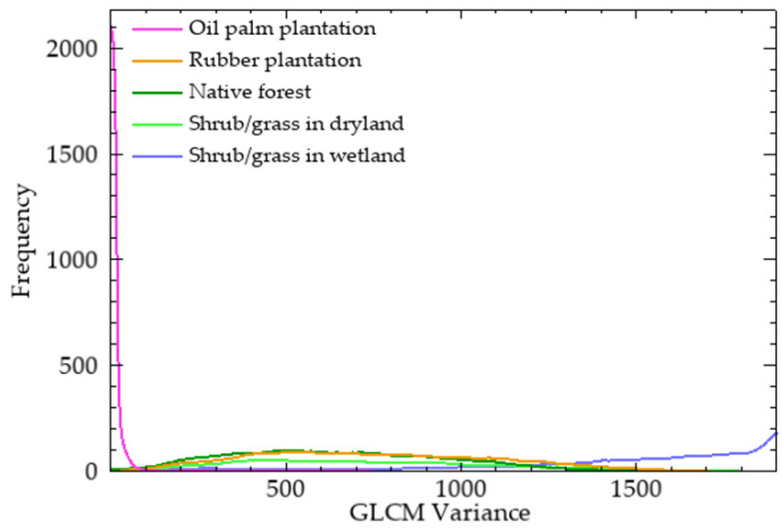

(f)

Figure 4. Histogram of oil palm plantation, rubber plantation native forest, and non-forest of shrub/grass in dryland and wetland derived from training samples: (a) VH, (b) VV, (c) VV/VH, (d) NDI, (e) VH - VV, and (f) GLCM variance. 


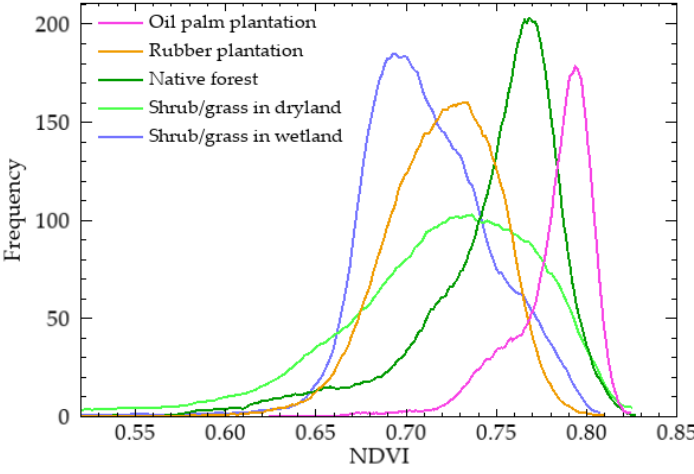

(a)

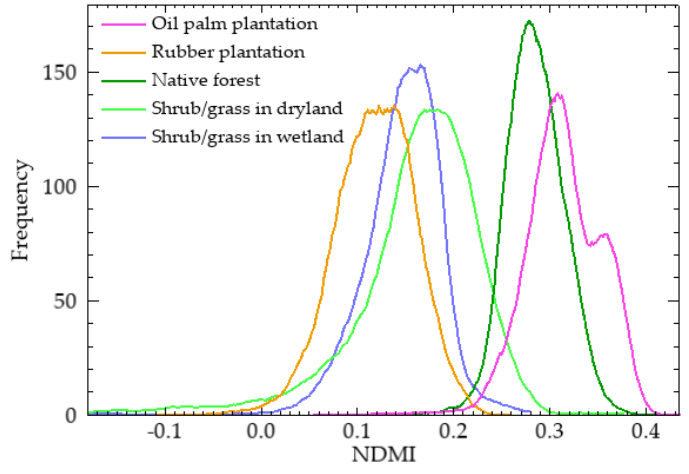

(b)

Figure 5. Histogram of rubber plantation, oil palm plantation, native forest, and non-forest of shrub/grass in dryland and wetland derived from training samples: (a) NDVI, and (b) NDMI.

Rubber plantations had relatively higher VH (Figure 4a) and lower VV (Figure 4b) compared to oil palm plantations, while the rubber plantation $\mathrm{VH}$ and VV backscatter values overlapped with native forests. However, the rubber plantation is relatively well distinguished from shrub and grasslands within the non-forest class based on higher $\mathrm{VH}$ and VV backscatter (Figure $4 a, b$ ).

Evaluation of rubber plantation indices based on the JM value showed that the use of NDVI and NDMI alone provided less accurate discrimination than when combined with VV and VH backscatter (Table 3). The JM value for discrimination of native forest and rubber plantations was 1.993, while the JM values for discrimination of rubber and non-forest in dryland and wetland were 1.977 and 1.721, respectively. Thus, the final indices and thresholds to discriminate the rubber plantations were an NDVI between 0.67 and 0.77, an NDMI of less than 0.2 , a VV backscatter between -8.5 and $-6 \mathrm{~dB}$, and a VH backscatter from -14 to $-12 \mathrm{~dB}$.

Table 3. JM value for rubber plantation discrimination from native forest and shrubs.

\begin{tabular}{cccc}
\hline Image Bands & $\begin{array}{c}\text { Native } \\
\text { Forest-Rubber }\end{array}$ & $\begin{array}{c}\text { Rubber-Non Forest } \\
\text { (Shrubs/ } \\
\text { Grass in Dryland) }\end{array}$ & $\begin{array}{c}\text { Rubber-Non Forest } \\
\text { (Shrubs/ } \\
\text { Grass in Wetland) }\end{array}$ \\
\hline NDVI, NDMI & 1.974 & 1.576 & 0.852 \\
NDVI, NDMI, VV, VH & 1.993 & 1.977 & 1.721 \\
\hline
\end{tabular}

\subsection{Land Cover Map and Validation}

The decision tree classification for discrimination of oil palm and rubber plantations to produce land cover map for 2018 is shown in Figure 6. This final land cover map comprised four classes: oil palm plantation, rubber plantation, native forest, and non-forest, as shown in Figure 7.

Spatial application of the decision tree showed that oil palm plantations were mainly located in the east of the study area (the region of Paser). Large-scale oil palm plantations were also detected in the central region of Tabalong (shown in the zoom box of Figure 7). This was validated with high spatial resolution SPOT 6 images acquired on 16 August 2018. Small areas of oil palm plantation were also scattered in the west of the region of Barito Timur.

Rubber plantations were mainly observed in the middle of the Tabalong and Balangan regions in relatively flat areas. Rubber plantations are also suitable to grow in relatively higher elevations and have been detected in the northwest of the Paser regency. The map also shows that rubber plantations have been established on a relatively small scale and are scattered within remnants of native forests. 


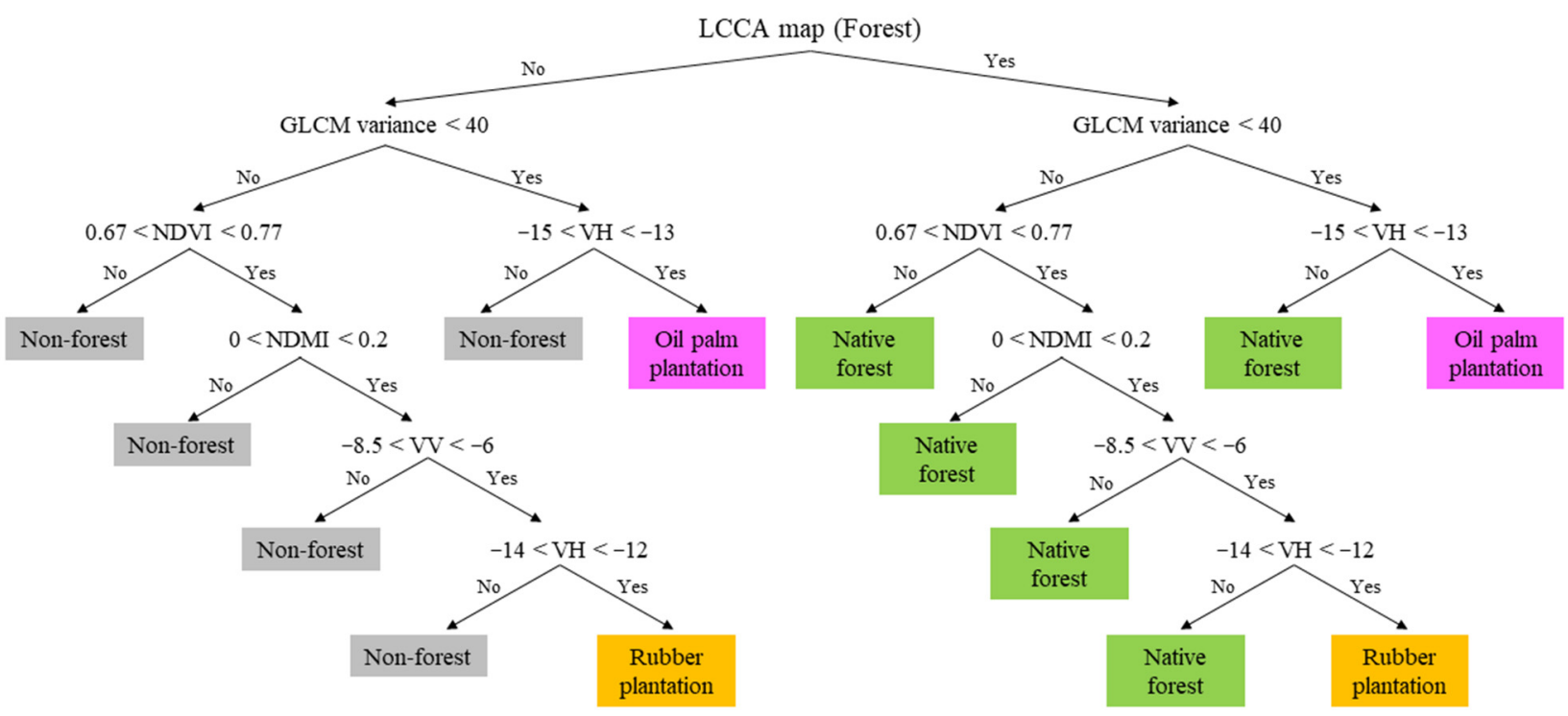

Figure 6. The decision tree to discriminate between native forest, oil palm plantation, rubber plantation, and non-forest.

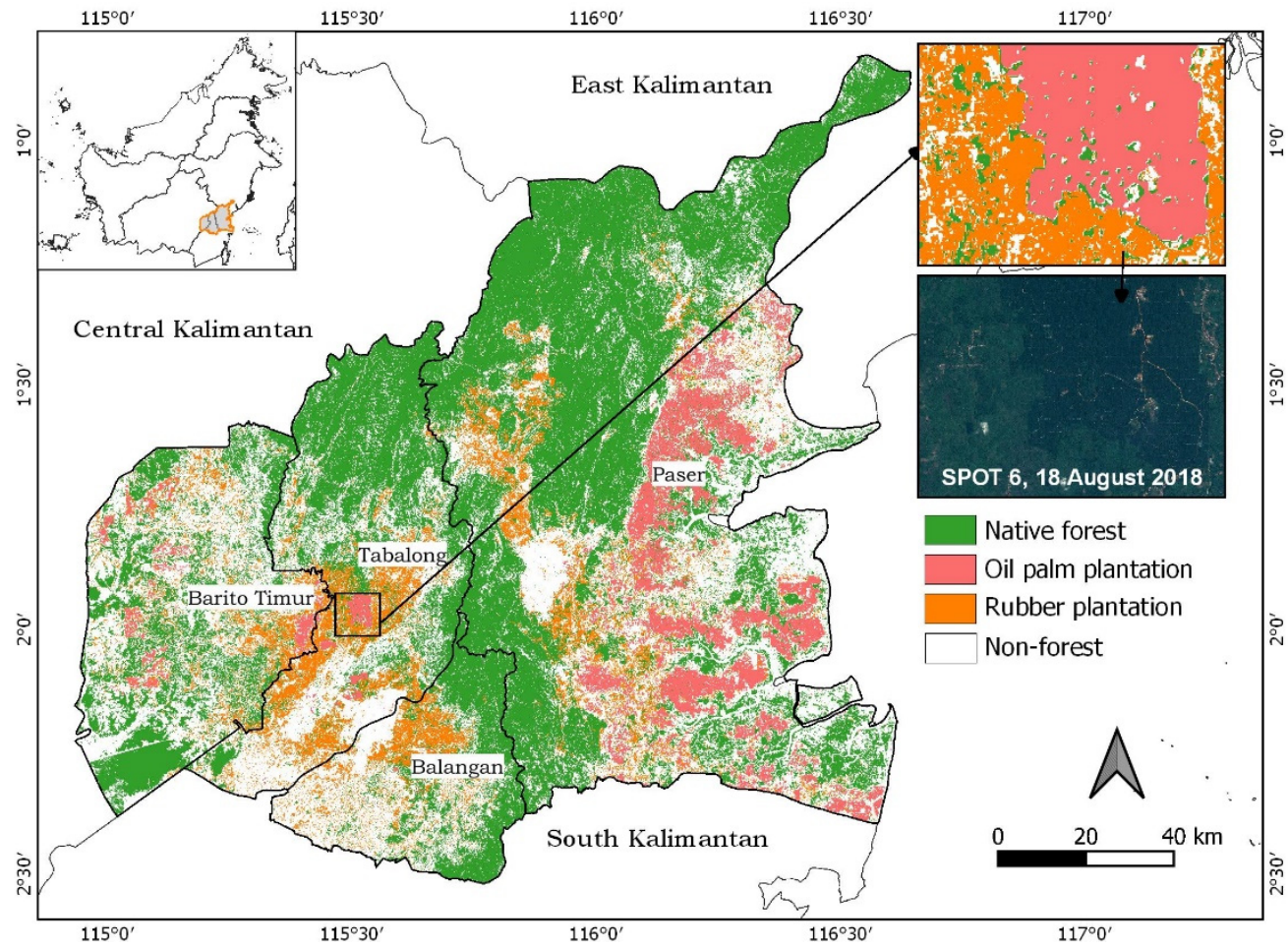

Figure 7. The land cover map of native forest, oil palm plantation, rubber plantation, and nonforest, 2018

Validation of the land cover map was assessed using a confusion matrix (Table 4). The overall accuracy was $92 \%$, with producer's accuracy for all classes higher than $90 \%$, except for rubber, which was $65 \%$. The native forest class had a producer's accuracy of $97 \%$ and a user's accuracy of $93 \%$ and showed good discrimination of native forest from other classes, particularly oil palm and rubber plantations. The commission error of $7 \%$ was largely attributable to misclassification of rubber plantations. 
Table 4. Accuracy assessment of the land cover map.

\begin{tabular}{|c|c|c|c|c|c|}
\hline \multirow{2}{*}{ Map } & \multicolumn{4}{|c|}{ Reference } & \multirow{2}{*}{ Total } \\
\hline & Native Forest & Oil Palm & Rubber & Non-Forest & \\
\hline Native forest & 342 & 2 & 16 & 7 & 367 \\
\hline Oil palm & 5 & 62 & 2 & 5 & 74 \\
\hline Rubber & 4 & 4 & 52 & 5 & 65 \\
\hline Non-forest & 1 & 0 & 10 & 267 & 278 \\
\hline \multirow[t]{2}{*}{ Total } & 352 & 68 & 80 & 284 & 784 \\
\hline & Comm. (\%) & Omiss. (\%) & $\begin{array}{c}\text { Producer's } \\
\text { Acc. (\%) }\end{array}$ & $\begin{array}{c}\text { User's } \\
\text { Acc. (\%) }\end{array}$ & $\begin{array}{r}\text { Overall } \\
\text { Acc. (\%) }\end{array}$ \\
\hline Native forest & 7 & 3 & 97 & 93 & \multirow{4}{*}{92} \\
\hline Oil palm & 16 & 9 & 91 & 84 & \\
\hline Rubber & 20 & 35 & 65 & 80 & \\
\hline Non-forest & 4 & 6 & 94 & 96 & \\
\hline
\end{tabular}

The oil palm plantation had a higher producer's accuracy of $91 \%$ and a user's accuracy of $84 \%$ compared to the rubber plantation. The rubber plantation class had the lowest accuracy, indicated by a $65 \%$ producer's accuracy and an $80 \%$ user's accuracy. This was identified from the omission error of $35 \%$ for the rubber plantation and is likely due to difficulty discriminating between native forests with lower tree density and rubber plantations.

\section{Discussion}

This study demonstrated the use of multi-source indices derived from optical and SAR images for land cover mapping. The study resulted in improvement in land cover classification accuracy relative to existing Indonesian forest maps (LCCA). Specifically, the method developed improved the ability to discriminate between native forest and oil palm and rubber plantations. Previous studies showed that the LCCA forest and nonforest map, which uses optical Landsat images, had lower overall accuracy $(73-77 \%)$ due to misclassification of plantations [31]. The integration of Landsat-8 OLI and Sentinel-1 C-band increased land cover classification accuracy, resulting in an overall accuracy of $92 \%$, with an increase in accuracy for the four classes (native forest, oil palm plantation, rubber plantation, and non-forest). Moreover, the multi-source approach resulted in producer's and user's accuracy for most land cover classes of more than 85\% [63] (Table 4), which fulfills Indonesia's desired criteria for map accuracy [64]. The exception was the accuracy for the rubber plantation class, which had a producer's accuracy of $65 \%$ and a user's accuracy of $80 \%$.

The native forest class had the highest producer's accuracy (97\%) and user's accuracy $(93 \%)$, while the non-forest class was the next most accurate with a producer's accuracy of $94 \%$ and a user's accuracy of $96 \%$. This high classification accuracy of native forest and non-forest classes was a direct result of explicitly separating oil palm and rubber plantation classes. Although oil palm plantations had an omission error of $9 \%$ and a commission error of $16 \%$, the oil palm class had a high producer's accuracy of $91 \%$ and user's accuracy of $84 \%$.

The high classification accuracy for oil palm plantations showed the benefit of integrating C-band data from the Sentinel-1 images, particularly in discriminating other closedcanopy forests (cover $>50 \%$ ) such as native forests and rubber plantations (Figure 3a). This is in contrast to optical images, which have shown limitations in discriminating vegetation with dense canopy cover.

In agreement with Miettinen et al. [23], the Sentinel-1 C-band could discriminate oil palm plantations based on the differences between VV and VH backscatter. This is likely due to the vegetation structure of oil palm plantations, which differs from that of rubber plantations and native forests. Oil palm plantations have a high VV backscatter due to 
canopy scattering from a large crown and fronds, while VH backscatter was low compared to other vegetation classes due to the low density of stems (Figure 3a,b).

The lower accuracy for mapping rubber plantations could be due to dependency on discriminating rubber plantations based on C-band SAR. The current study used optical Landsat- 8 images of less than $50 \%$ cloud cover in combination with the relatively short wavelength of the Sentinel-1 C-band. This wavelength is less likely to penetrate through the canopy and differentiate between the distinct mid- and understory of native forest and rubber plantations. Use of longer wavelengths with greater penetration, such as the L-band (wavelength $\sim 23.5 \mathrm{~cm}$ ) from ALOS PALSAR, would result in greater penetration through the canopy and more distinct scattering from trunks and branches, twigs, and ground cover vegetation [65].

The other causes of the low accuracy of rubber plantation discrimination may be the calibration of the SAR digital numbers using sigma nought. The sigma nought may produce significant variation of the backscatter coefficients depending on the incidence angle, wavelength, polarization, topography and land surface [66]. Therefore, previous studies showed that image calibration using gamma nought results in improvements in classification, particularly for mapping forest types based on variations in structure across varying topography $[19,67]$.

The current study indicates that rubber plantations have an NDVI ranging from 0.67 to 0.77 , which is lower than the NDVI expected for native forests $(<0.80)$ (Figure 5a). This is in agreement with previous studies, where time-series images of rubber plantation NDVI showed values of less than 0.80 , while native forests, including temperate and tropical forests, had an NDVI of up to 0.9 [68,69].

NDMI is sensitive to the moisture content of leaves. An NDMI of greater than 0.28 indicates healthy vegetation with dense canopy cover, while bare soil has low and negative values of the index $[60,70]$. For example, native evergreen forest has been shown to produce an NDMI of more than 0.40 all year [71]. The low value of NDMI for rubber plantations may be caused by low stem density and semi-open canopy, leading to drying of the soil [72]. For this reason, rubber plantations were discriminated from native forest using a threshold of less than 0.2. However, the NDMI threshold works as a function of vegetation area fraction that does not significantly differ for wet or dry soil areas [73].

In tropical regions, shrubs are often misclassified as plantation and forest regrowth, particularly in their early years [74-76]. Thus, shrubs and grassland had an overlap with rubber plantations with respect to their NDVI and NDMI distributions (Figure 5). The shorter C-band wavelength is sensitive to shrub, grass, and low vegetation structure and showed a relatively low backscatter value for both $\mathrm{VV}$ and $\mathrm{VH}$ polarization compared to rubber plantations [66]. Therefore, backscatter of VV and VH was applied to discriminate shrubs from rubber plantations, which increased the rubber class separability quantified by the JM value (Table 3 ).

Our study resulted in the generation of a land cover map in 2018. However, this should not necessarily be seen as a final product. It is important to realize that spatio-temporal processing steps are required to improve the mapping accuracy and temporal consistency of the land cover classifications by reducing unlikely transitions between classes. For example, implementation of the multitemporal processing method using a Bayesian Hidden Markov model can be used to combine continuous and discrete variables to improve classification accuracy $[77,78]$.

\section{Conclusions}

Accurate and timely information of land cover and land cover change is required to help countries in the tropics to comply with the IPCC principles of transparency, comparability, consistency, completeness, and accuracy for sustainable forest management and investment decisions. Indonesia's national forest monitoring system currently relies on mapping two land cover classes of forest and non-forest. This study developed multi-source indices to discriminate between native forests and tree plantations, such as oil palm and 
rubber, by integrating optical Landsat-8 and Sentinel-1 SAR images. The use of SAR images helped to improve the accuracy of forest mapping, which is currently strongly impacted by frequent cloud cover. Integration of multi-source images provides more comprehensive information on which to base land cover classification. Landsat- 8 images can differentiate vegetation types such as rubber plantations from spectral indices such as NDVI and NDMI, while Sentinel-1 C-band SAR can be used to differentiate between native forest and tree plantations based on backscatter characteristics.

The current study shows integration of optical and SAR images improved classification with an overall accuracy of $92 \%$. All four of the land cover classes fulfilled the minimum target accuracy, except for rubber plantations. Therefore, improvement of the current method using applications of multitemporal processing will be required in order to develop a final product. Once this has been achieved, this method can be used to extend Indonesia's national mapping to four land cover classes of native forest, oil palm plantation, rubber plantation, and non-forest.

Author Contributions: Conceptualization, methodology, and formal analysis: I.L.S., L.V., C.J.W. and G.J.N.; software, visualization, investigation, and writing-original draft preparation, I.L.S.; supervision and writing-review and editing: L.V., C.J.W. and G.J.N. All authors have read and agreed to the published version of the manuscript.

Funding: This research received no external funding.

Institutional Review Board Statement: Not applicable.

Informed Consent Statement: Not applicable.

Data Availability Statement: The data presented in this study are available on request from the corresponding author.

Acknowledgments: We thank reviewers for their valuable comments. We would like to thank the Indonesian National Institute of Aeronautics and Space (LAPAN-BRIN) for sharing the satellite images. We thank the LCCA teams of LAPAN, the Indonesia-Australia Forest Carbon Partnership (IAFCP) for sharing data (i.e., Landsat mosaic, forest cover indices, and threshold for 2000-2014) and methods. I.L.S acknowledges the Indonesian Endowment Fund for Education (LPDP) for PhD scholarship.

Conflicts of Interest: The authors declare no conflict of interest.

\section{References}

1. FAO. FAOSTAT. Available online: http:/ / www.fao.org/faostat/en/\#data (accessed on 6 June 2021).

2. Austin, K.G.; Schwantes, A.; Gu, Y.F.; Kasibhatla, P.S. What causes deforestation in Indonesia? Environ. Res. Lett. 2019, 14, 9. [CrossRef]

3. Ocampo-Peñuela, N.; Garcia-Ulloa, J.; Kornecki, I.; Philipson, C.D.; Ghazoul, J. Impacts of four decades of forest loss on vertebrate functional habitat on Borneo. Front. For. Glob. Chang. 2020, 3, 53. [CrossRef]

4. Carlson, K.M.; Curran, L.M.; Ratnasari, D.; Pittman, A.M.; Soares-Filho, B.S.; Asner, G.P.; Trigg, S.N.; Gaveau, D.A.; Lawrence, D.; Rodrigues, H.O. Committed carbon emissions, deforestation, and community land conversion from oil palm plantation expansion in West Kalimantan, Indonesia. Proc. Natl. Acad. Sci. USA 2012, 109, 7559. [CrossRef]

5. Ustin, S.L. Remote Sensing for Natural Resource Management and Environmental Monitoring; John Wiley: New York, NY, USA, 2004; pp. 1-729.

6. Vancutsem, C.; Achard, F.; Pekel, J.F.; Vieilledent, G.; Carboni, S.; Simonetti, D.; Gallego, J.; Aragão, L.E.O.C.; Nasi, R. Long-term (1990-2019) monitoring of forest cover changes in the humid tropics. Sci. Adv. 2021, 7, eabe1603. [CrossRef]

7. Caccetta, P.; Furby, S.; Wallace, J.; Wu, X.; Richards, G.; Waterworth, R. Long-term monitoring of Australian land cover change using Landsat data: Development, implementation, and operation. In Global Forest Monitoring from Earth Observation; Achard, F., Hansen, M.C., Eds.; Taylor \& Francis: New York, NY, USA, 2013. [CrossRef]

8. Hansen, M.C.; Potapov, P.V.; Moore, R.; Hancher, M.; Turubanova, S.; Tyukavina, A.; Thau, D.; Stehman, S.V.; Goetz, S.J.; Loveland, T.R. High-resolution global maps of 21st-century forest cover change. Science 2013, 342, 850-853. [CrossRef] [PubMed]

9. Margono, B.A.; Usman, A.B.; Sugardiman, R.A. Indonesia's forest resource monitoring. Indones. J. Geogr. 2016, 48, 7-20. [CrossRef]

10. LAPAN. The Remote Sensing Monitoring Program of Indonesia's National Carbon Accounting System: Methodology and Products, Version 1; LAPAN-IAFCP: Jakarta, Indonesia, 2014; pp. 15-78. Available online: http://incas.menlhk.go.id/methodology/incasstandard-method-forest-cover-change/ (accessed on 4 January 2019). 
11. Directorate General of Climate Change, Ministry of Environment and Forestry. National Forest Reference Emission Level for Deforestation and Forest Degradation: In the Context of Decision 1/CP.16 Para 70 UNFCCC (Encourages Developing Country Parties to Contribute to Mitigation Actions in the Forest Sector); Ministry of Environment and Forestry: Jakarta, Indonesia, 2016; pp. 6-7. Available online: https://redd.unfccc.int/files/frel_submission_by_indonesia_final.pdf (accessed on 26 April 2020).

12. Tropek, R.; Sedláček, O.; Beck, J.; Keil, P.; Musilová, Z.; Šímová, I.; Storch, D. Comment on “High-resolution global maps of 21st-century forest cover change". Science 2014, 344, 981. [CrossRef]

13. Kustiyo, K.; Roswintiarti, O.; Tjahjaningsih, A.; Dewanti, R.; Furby, S.; Wallace, J. Annual forest monitoring as part of the Indonesia's National Carbon Accounting System. Int. Arch. Photogramm. Remote Sens. Spat. Inf. Sci. 2015, 40-47, 441. [CrossRef]

14. Torbick, N.; Ledoux, L.; Salas, W.; Zhao, M. Regional mapping of plantation extent using multisensor imagery. Remote Sens. 2016, 8, 236. [CrossRef]

15. Asner, G.P. Cloud cover in Landsat observations of the Brazilian Amazon. Int. J. Remote Sens. 2001, 22, 3855-3862. [CrossRef]

16. Ministry of Environment and Forestry, Republic of Indonesia. The State of Indonesia's Forests 2018; Ministry of Environment and Forestry, Republic of Indonesia: Jakarta, Indonesia, 2018; p. 10. Available online: https:/ /www.menlhk.go.id/site/download? start=10 (accessed on 14 May 2019).

17. Tarko, A.; Tsendbazar, N.-E.; De Bruin, S.; Bregt, A.K. Producing consistent visually interpreted land cover reference data: Learning from feedback. Int. J. Digit. Earth 2021, 14, 52-70. [CrossRef]

18. DeFries, R.; Achard, F.; Brown, S.; Herold, M.; Murdiyarso, D.; Schlamadinger, B.; De Souza, C. Earth observations for esti-mating greenhouse gas emissions from deforestation in developing countries. Environ. Sci. Policy 2007, 10, 385-394. [CrossRef]

19. Hoekman, D.H. Radar backscattering of forest stands. Int. J. Remote Sens. 1985, 6, 325-343. [CrossRef]

20. Oon, A.; Ngo, K.D.; Azhar, R.; Ashton-Butt, A.; Lechner, A.M.; Azhar, B. Assessment of ALOS-2 PALSAR-2 L-band and Sentinel-1 C-band SAR backscatter for discriminating between large-scale oil palm plantations and smallholdings on tropical peatlands. Remote Sens. Appl. Soc. Environ. 2019, 13, 183-190. [CrossRef]

21. Shimada, M.; Itoh, T.; Motooka, T.; Watanabe, M.; Shiraishi, T.; Thapa, R.; Lucas, R. New global forest/non-forest maps from ALOS PALSAR data (2007-2010). Remote Sens. Environ. 2014, 155, 13-31. [CrossRef]

22. Lehmann, E.A.; Caccetta, P.A.; Lowell, K.; Mitchell, A.; Zhou, Z.S.; Held, A.; Milne, T.; Tapley, I. SAR and optical remote sensing: Assessment of complementarity and interoperability in the context of a large-scale operational forest monitoring sys-tem. Remote Sens. Environ. 2015, 156, 335-348. [CrossRef]

23. Miettinen, J.; Liew, S.C.; Kwoh, L.K. In Usability of Sentinel-1 dual polarization C-band data for plantation detection in insular Southeast Asia. In Proceedings of the 36th Asian Conference on Remote Sensing (ACRS2015), Quezon City, Philippines, 24-28 October 2015.

24. Miettinen, J.; Liew, S.C. Separability of Insular Southeast Asian woody plantation species in the 50 m resolution ALOS PALSAR mosaic product. Remote Sens. Lett. 2011, 2, 299-307. [CrossRef]

25. Dong, J.; Xiao, X.; Sheldon, S.; Biradar, C.; Xie, G. Mapping tropical forests and rubber plantations in complex landscapes by integrating PALSAR and MODIS imagery. ISPRS J. Photogramm. Remote Sens. 2012, 74, 20-33. [CrossRef]

26. Guido, C.; Barry, N.H. Supervised machine learning of fused radar and optical data for land cover classification. J. Appl. Remote Sens. 2012, 6, 063597. [CrossRef]

27. Tsujino, R.; Yumoto, T.; Kitamura, S.; Djamaluddin, I.; Darnaedi, D. History of forest loss and degradation in Indonesia. Land Use Pol. 2016, 57, 335-347. [CrossRef]

28. Gaveau, D.L.A.; Locatelli, B.; Salim, M.A.; Yaen, H.; Pacheco, P.; Sheil, D. Rise and fall of forest loss and industrial plantations in Borneo (2000-2017). Conserv. Lett. 2018, 12, e12622. [CrossRef]

29. Directorate General of Estate Crops, Ministry of Agriculture. Tree Crop Estate Statistics of Indonesia: Palm Oil 2017-2019; Di-rectorate General of Estate Crops, Ministry of Agriculture: South Jakarta, Indonesia, 2018. Available online: https://drive.google.com/ file/d/1rlmMNUbPM99DA-Ywo-Prv3cmPnWoFUUp/view (accessed on 23 May 2020).

30. Directorate General of Estate Crops, Ministry of Agriculture. Tree Crop Estate Statistics of Indonesia: Rubber 2017-2019; Di-rectorate General of Estate Crops, Ministry of Agriculture: South Jakarta, Indonesia, 2018. Available online: https://drive.google.com/ file/d/1hF-ilorfxR8Hx5wxroRWOBpKoNzOlLBL/view (accessed on 23 May 2020).

31. Sari, I.L.; Weston, C.J.; Newnham, G.J.; Volkova, L. Assessing accuracy of land cover change maps derived from automated digital processing and visual interpretation in tropical forests in Indonesia. Remote Sens. 2021, 13, 1446. [CrossRef]

32. Penman, J.; Gytarsky, M.; Hiraishi, T.; Krug, T.; Kruger, D.; Pipatti, R.; Buendia, L.; Miwa, K.; Ngara, T.; Tanabe, K. Good Practice Guidance for Land Use, Land-Use Change and Forestry; Institute for Global Environmental Strategies (IGES): Hayama, Kanagawa, Japan, 2003. Available online: https://www.ipcc.ch/site/assets/uploads/2018/03/GPG_LULUCF_FULLEN.pdf (accessed on 9 January 2021).

33. Division of Integrated Data Processing Integration and Statistical Disemination, BPS-Statistics of Kalimantan Tengah Province. Provinsi Kalimantan Tengah Dalam Angka 2018 (Kalimantan Tengah Province in Figures 2018); BPS-Statistics of Kalimantan Tengah Province: Palangka Raya, Indonesia, 2018; Volume 10, pp. 326-327. Available online: https:/ / kalteng.bps.go.id/publication/20 18/08/16/ceed046d35684aefde786f04/provinsi-kalimantan-tengah-dalam-angka-2018.html (accessed on 23 May 2020). 
34. Division of Integrated Data Processing Integration and Statistical Disemination, BPS-Statistics of Kalimantan Timur Province. Provinsi Kalimantan Timur Dalam Angka 2018 (Kalimantan Timur Province in Figures 2018); BPS-Statistics of Kalimantan Timur Province: Samarinda, Indonesia, 2018; Volume 9, pp. 249-250. Available online: https://kaltim.bps.go.id/publication/2018/08/ 16/9341dae4a1306ccfee98a393/provinsi-kalimantan-timur-dalam-angka-2018.html (accessed on 23 May 2020).

35. Division of Integrated Data Processing Integration and Statistical Disemination, BPS-Statistics of Kalimantan Selatan Province. Provinsi Kalimantan Selatan Dalam Angka 2018 (Kalimantan Selatan Province in Figures 2018); BPS-Statistics of Kalimantan Selatan Province: Banjarbaru, Indonesia, 2018; Volume 7, pp. 230-231. Available online: https://kalsel.bps.go.id/publication/2018/08/ 16/f646d3011e4c3dfb0a4cbd74/provinsi-kalimantan-selatan-dalam-angka-2018.html (accessed on 23 May 2020).

36. Sidiyasa, K. Tree diversity in the rain forest of Kalimantan. In Proceedings of the Balance between Biodiversity Conservation and Sus-Tainable Use of Tropical Rain Forest, Wageningen, The Netherlands, 2001; pp. 69-78. Available online: https://www. tropenbos.org/resources/publications/tree+diversity+in+the+rain+forest+of+kalimantan (accessed on 28 May 2019).

37. Mackinnon, K.; Hatta, G.; Halim, H.; Mangalik, A. The Ecology of Kalimantan; Periplus Editions (HK) Ltd.: Hong Kong, 1996; pp. 175-310.

38. Ngatiman, N.; Saridan, A. Ekplorasi jenis-jenis Dipterokarpa di Kabupaten Paser, Kalimantan Timur (Exploration of Dipter-ocarps species in Paser Regency, East Kalimantan). J. Penelit. Ekosist. Dipterokarpa 2012, 6, 1-10. [CrossRef]

39. Corley, R.H.V.; Tinker, P.B. The Oil Palm; Wiley-Blackwell: West Sussex, UK, 2016; pp. 53-134.

40. Phuc, T.X.; Nghi, T.H. Rubber Expansion and Forest Protection in Vietnam; Tropenbos International Viet Nam: Hue, Vietnam, 2014; Available online: https://www.tropenbos.org/resources/publications/rubber+expansion+and+forest+protection+in+vietnam (accessed on 28 May 2019).

41. World Agroforestry. Agroforestree Database. Available online: http://apps.worldagroforestry.org/treedb/AFTPDFS/Hevea_ brasiliensis.PDF (accessed on 12 July 2021).

42. Setyawati, T.; Narulita, S.; Bahri, I.P.; Raharjo, G.T. A Guide Book to Invasive Plant Species in Indonesia; Research, Development and Innovation Agency, Ministry of Environment and Forestry Republic of Indonesia: Bogor, Indonesia, 2015; pp. 17, 159, 207. Available online: http://ksdae.menlhk.go.id/assets/publikasi/A_Guide_Book_of_Invasive_Plant_Species_in_Indonesia.pdf (accessed on 10 August 2021).

43. Tamai, Y.; Sandan, P.; Gaman, S.; Prawira, Y. Ethnic plant resources in Central Kalimantan. In Tropical Peatland Ecosystems; Osaki, M., Tsuji, N., Eds.; Springer: Tokyo, Japan, 2016. [CrossRef]

44. Barker, P.C.J. A Technical Manual for Vegetation Monitoring/Phil Barker; Resource Management and Conservation, Department of Primary Industries, Water and Environment: Hobart, TAS, Australia, 2001.

45. Mueller-Dombois, D.; Bridges, K.W.; Deahler, C. Biodiversity Assessment of Tropical Island Ecosystems, PABITRA Manual for Interactive Ecology and Management; Bishop Museum Press: Honolulu, HI, USA, 2008; pp. 17-48.

46. Schomaker, M.E.; Zarnoch, S.J.; Bechtold, W.A.; Latelle, D.J.; Burkman, W.G.; Cox, S.M. Crown-Condition Classification: A Guide to Data Collection and Analysis; General Technical Report SRS-102; USDA Forest Services: Washington, DC, USA, 2007. [CrossRef]

47. Kvamme, C.D. A Comparison of Ground Cover and Frequency Estimation Methods for Post-Harvest Soil Monitoring. Master's Thesis, Michigan Technological University, Houghton, MI, USA, 2010. Available online: https://digitalcommons.mtu.edu/ cgi/viewcontent.cgi?article=1142\&context=etds (accessed on 23 April 2021).

48. Haglöf, A.B. Users Guide Vertex III and Transponder T3; Haglöf Sweden, AB: Långsele, Sweden, 2002.

49. Friedl, M.A.; Brodley, C.E. Decision Tree classification of land cover from remotely sensed data. Remote Sens. Environ. 1997, 61, 399-409. [CrossRef]

50. Li, L.; Dong, J.; Njeudeng Tenku, S.; Xiao, X. Mapping oil palm plantations in Cameroon using PALSAR 50-m orthorectified mosaic images. Remote Sens. 2015, 7, 1206-1224. [CrossRef]

51. Simard, M.; Saatchi, S.S.; Grandi, G.D. The use of decision tree and multiscale texture for classification of JERS-1 SAR data over tropical forest. IEEE Trans. Geosci. Remote. Sens. 2000, 38, 2310-2321. [CrossRef]

52. Haralick, R.M.; Shanmugam, K.; Dinstein, I. Textural features for image classification. IEEE Trans. Syst. Man Cybern. 1973, SMC-3, 610-621. [CrossRef]

53. Zhang, C.; Huang, C.; Li, H.; Liu, Q.; Li, J.; Bridhikitti, A.; Liu, G. Effect of textural features in remote sensed data on rubber plantation extraction at different levels of spatial resolution. Forests 2020, 11, 399. [CrossRef]

54. Kuffer, M.; Sliuzas, R.; Pfeffer, K.; Baud, I. The utility of the co-occurrence matrix to extract slum areas from VHR imagery. In Proceedings of the 2015 Joint Urban Remote Sensing Event (JURSE), Lausanne, Switzerland, 30 March-1 April 2015; pp. 1-4.

55. Baraldi, A.; Panniggiani, F. An investigation of the textural characteristics associated with Gray Level Cooccurrence Matrix statistical parameters. IEEE Trans. Geosci. Remote Sens. 1995, 33, 293-304. [CrossRef]

56. Jensen, J.R. Introductory Digital Image Processing: A Remote Sensing Perspective, 3rd ed.; Prentice Hall: Upper Saddle River, NJ, USA, 2005; pp. 364-370.

57. Congedo, L. Semi-Automatic Classification Plugin: A Python tool for the download and processing of remote sensing images in QGIS. J. Open Source Softw. 2021, 6, 3172. [CrossRef]

58. Razak, J.A.B.A.; Shariff, A.R.B.; Ahmad, N.; Sameen, M.I. Mapping rubber trees based on phenological analysis of Landsat time series data-sets. Geocarto Int. 2018, 33, 627-650. [CrossRef]

59. Xiao, C.; Li, P.; Feng, Z. How did deciduous rubber plantations expand spatially in China's Xishuangbanna Dai Autonomous Prefecture during 1991-2016? Photogramm. Eng. Remote 2019, 85, 687-697. [CrossRef] 
60. Beckschäfer, P. Obtaining rubber plantation age information from very dense Landsat TM \& ETM+ time series data and pix-el-based image compositing. Remote Sens. Environ. 2017, 196, 89-100. [CrossRef]

61. Senf, C.; Pflugmacher, D.; Van der Linden, S.; Hostert, P. Mapping rubber plantations and natural forests in Xishuangbanna (Southwest China) using Multi-Spectral Phenological Metrics from MODIS Time Series. Remote Sens. 2013, 5, $2795-2812$. [CrossRef]

62. Olofsson, P.; Foody, G.M.; Herold, M.; Stehman, S.V.; Woodcock, C.E.; Wulder, M.A. Good practices for estimating area and assessing accuracy of land change. Remote Sens. Environ. 2014, 148, 42-57. [CrossRef]

63. Anderson, J.R. A Land Use and Land Cover Classification System for Use with Remote Sensor Data; Geological Survey Professional Paper No. 964; US Government Printing Office: Washington, DC, USA, 1976.

64. Karsidi, A.; Geospatial Information Agency of Indonesia. Peraturan Kepala Badan Informasi Geospasial Nomor 15 Tahun 2014 Ten-Tang Pedoman Teknis Ketelitian Peta Dasar (Head of Geospatial Information Agency: Technical Guidelines to Determine the Accuracy of the Base Map Number 15 Year 2014); Geospatial Information Agency of Indonesia: Cibinong, Indonesia, 2014; p. 15. Available online: https://jdih.big.go.id/media/resources/files/law/tUF25Yj2xW_Perka_Ketelitian_Peta_Dasar_-_Salinan.pdf (accessed on 12 July 2021).

65. Rosenqvist, Å. Evaluation of JERS-1, ERS-1 and Almaz SAR backscatter for rubber and oil palm stands in West Malaysia. Int. J. Remote Sens. 1996, 17, 3219-3231. [CrossRef]

66. CEOS-Committee on Earth Observation Satellites. A Layman's Interpretation to L-Band and C-Band Synthetic Aperture Radar Data. Available online: https://ceos.org/document_management/SEO/DataCube/Laymans_SAR_Interpretation_Guide_2.0. pdf (accessed on 11 June 2021).

67. Hoekman, D.H.; Vissers, M.A.M.; Wielaard, N. PALSAR wide-area mapping of Borneo: Methodology and map validation. IEEE J. Sel. Top. Appl. Earth Observ. Remote Sens. 2010, 3, 605-617. [CrossRef]

68. Xiao, C.; Li, P.; Feng, Z.; Liu, X. An updated delineation of stand ages of deciduous rubber plantations during 1987-2018 using Landsat-derived bi-temporal thresholds method in an anti-chronological strategy. Int. J. Appl. Earth Obs.-Vation Geoinf. 2019, 76, 40-50. [CrossRef]

69. Huete, A.R.; Liu, H.Q.; Batchily, K.; van Leeuwen, W. A comparison of vegetation indices over a global set of TM images for EOS-MODIS. Remote Sens. Environ. 1997, 59, 440-451. [CrossRef]

70. Grogan, K.; Pflugmacher, D.; Hostert, P.; Kennedy, R.; Fensholt, R. Cross-border forest disturbance and the role of natural rubber in mainland Southeast Asia using annual Landsat time series. Remote Sens. Environ. 2015, 169, 438-453. [CrossRef]

71. Li, P.; Zhang, J.H.; Feng, Z.M. Mapping rubber tree plantations using a Landsat-based phenological algorithm in Xishuang-banna, Southwest China. Remote Sens. Lett. 2015, 6, 49-58. [CrossRef]

72. Nurulita, Y.; Adetutu, E.M.; Kadali, K.K.; Zul, D.; Mansur, A.A.; Ball, A.S. The assessment of the impact of oil palm and rubber plantations on the biotic and abiotic properties of tropical peat swamp soil in Indonesia. Int. J. Agric. Sustain. 2015, 13, 150-166. [CrossRef]

73. Gao, B.C. NDWI-A normalized difference water index for remote sensing of vegetation liquid water from space. Remote Sens. Environ. 1996, 58, 257-266. [CrossRef]

74. Helmer, E.H.; Brown, S.; Cohen, W.B. Mapping montane tropical forest successional stage and land use with multi-date Landsat imagery. Int. J. Remote Sens. 2000, 21, 2163-2183. [CrossRef]

75. Sánchez-Azofeifa, G.A.; Castro, K.L.; Rivard, B.; Kalascka, M.R. Remote sensing research priorities in tropical dry forest en-vironments. Biotropica 2003, 35, 134-142. [CrossRef]

76. Zhongchang, S.; Patrick, L.; Huadong, G.; Chong, H.; Claudia, K. Extracting distribution and expansion of rubber plantations from Landsat imagery using the C5.0 decision tree method. J. Appl. Remote Sens. 2017, 11, 026011. [CrossRef]

77. Symeonakis, E.; Caccetta, P.A.; Koukoulas, S.; Furby, S.; Karathanasis, N. Multi-temporal land-cover classification and change analysis with conditional probability networks: The case of Lesvos Island (Greece). Int. J. Remote Sens. 2012, 33, 4075-4093. [CrossRef]

78. Reiche, J.; De Bruin, S.; Hoekman, D.; Verbesselt, J.; Herold, M. A Bayesian approach to combine Landsat and ALOS PALSAR time series for Near Real-Time deforestation detection. Remote Sens. 2015, 7, 4973-4996. [CrossRef] 